\title{
Soil Erosion: the Growth of the Desert in Africa and Elsewhere*
}

\author{
By Sir Daniel Hall, K.C.B., F.R.S.
}

$\mathrm{U}^{\mathrm{s}}$ SUALLY the soil is regarded as something particularly stable, but this stability is almost wholly due to its normal covering of vegetation. There is always a danger that if the cover of vegetation is removed the soil itself will begin to move under the action of either the wind or the rain. Rarely do we see these actions at work on a large scale in England; the climatic conditions are not favourable, for our rainfall is gentle and evenly distributed throughout the year, and our big winds are mostly associated with rain. It is in semi-arid regions, where long periods of drought may be followed by torrential rains, that soil erosion becomes an active danger.

The earliest cases of erosion to be noticed are those which follow deforestation in regions where the mountains in which the rivers take their rise are below the permanent snow-line. In such countries, typically in the eastern Mediterranean -Calabria, Greece, the greater part of Asia Minorthe natural sequence is forest on the higher slopes where the rainfall is greatest, passing into upland meadows as the slope grows less and finally into river meadows as the river nears the sea. There is no evidence in support of the belief that forests increase the rainfall of a country; but they. serve as its regulator. The spongy soil below the trees, rich in humus, absorbs the rain as it falls, whereby it reappears later in the springs and furmishes the watercourses and rivers when the rainy season has passed. But too commonly the forests have been cut down without any regard to their regeneration; not only has the maximum of timber been cut out but there has also been the desire to extend the grazing, and unfortunately in these Mediterranean countries goats are among the chief grazing animals. Hungry goats will eat anything that grows; they destroy every seedling tree as fast as it gets its head up, they complete and extend the destruction the woodcutters have begun. At the same time, with their sharp hooves they break the surface of the soil ; in other places they tread hard paths down which the rain begins to run with gathering volume and velocity. In a very short time during the rains, gullies begin to form as the soil is washed downhill; year by year the gullies extend and bite deeper into the earth until in no long time-a generation or two-the hillsides that had been forest and upland meadow

* From a Friday evening discourse delivered at the Royal Institution on November 12. get bared down to the hard infertile subsoil or to the rock itself.

Nor does the damage end there; the rainfall running off the bared hill country without a check develops as a torrent lower down, attacking the meadows bordering its course. The earth also that has been washed off the hillsides is carried down to the plains where the rivers lose their velocity ; there it is deposited and turns the river into a chain of malarious swamps, chokes its mouth and destroys any harbour that was there. Such has been the history of much of the fairest land on the seaboard of the Levant ; on the heights, bare rock where once forest and meadow flourished, rivers that are torrents in winter and dry in summer, old seaports no longer accessible. The destruction of the forest was thus a major factor in the decay of Greece and of Rome itself ; it meant in the first place the loss of farming land and of the agricultural population which formed the backbone of the early armies of the republics. With the swamps came the spread of malaria, which again has been invoked as one of the great causes of the fall of ancient civilization.

The most spectacular form of soil erosion is that exhibited by the vast dust-storms which, in 1934 and 1935 especially, swept over the United States east of the Mississippi. A vast area, which included western Oklahoma, western Kansas, eastern Colorado, the Panhandle of Texas and parts of Wyoming, has become known as the Dust Bowl. In 1934 it was estimated that on a single day 300 million tons of rich top soil were swept as far away as the Atlantic. There is a story that in the diary of an old Nebraska doctor was found the entry "June 14th. Hot as hell, wind 40 miles an hour, two Kansas farms go by every minute".

The causes of this terrible wind erosion are easy to discern. It arises only in comparatively arid districts where the rainfall is below the 20 -inch level, and (in America in any event) where the fundamental subsoil is of a rather sandy type-a recent glacial drift. Before white settlement, these regions were clothed with grass and were the natural home of the buffalo. Some of the land was good grazing, with a fair depth of black soil rich in humus ; in the drier parts the sod was thin and there were only a few inches of soil. The black soil regions were fertile and were the first to be broken up ; the poorer land was kept for ranching, healthy for either cattle or sheep if not too closely 
stocked. The plough, however, began to encroach upon these thin soils, with great rapidity when prices of cereals went soaring up from 1917 onwards. At first all went well, for the cultivation began in a cycle of good rainfall seasons and there was some stock both of humus in the soil and of accumulated rainfall below. Years of drought followed when the original subsoil reserve of water had been used up, and the light soil, no longer bound together either by vegetation or humus, began to drift in the fierce winds that sweep over those great plains. The plough has destroyed the binding power of the soil ; the wind is then able to remove the whole of the fertile top layer of soil and leave nothing but the denser subsoil, which is too infertile to carry a crop. Nor has it been the case that the good soil is merely transferred from one farm to the next; as a rule in Canada it has been swept right away into the Great Lakes or the barren lands to the north, or even into the Atlantic itself.

Without doubt, much of the poorest of this land ought never to have been ploughed even in boom times; once the crust has been broken it becomes a sort of running sore always eating into the land on its margin. As a ranch under its natural vegetation it had a modest productive value, and to that use it must return.

In Canada, improved methods of cultivation have been introduced to minimize the danger of soil drifting. Since it is inevitable that at certain seasons of the year the soil should be cultivated while bare of a crop, the practice has been introduced of dividing the land into strips, the bare land alternating with land under crop in place of the former large areas under the same treatment. Thus the incipient soil erosion under the wind is checked before it can proceed far, and a very efficient measure of protection is attained.

One other major work of reconstruction is needed, though it is being taken in hand on a large scale in the United States, and that is the establishment of shelter belts to break up the fierce winds which rage over these open treeless spaces. It is not an easy matter to get trees started, especially the north in Saskatchewan and Alberta, where the range of species that will stand up to the extremes of climate is limited, but a certain number of suitable species have been found. Besides the original planting of crosscountry belts, farmers are being taught to protect their own holdings.

Erosion by rain is even more common wherever the cultivated land lies on a slope and the rains are heavy. The danger does not lie in a large annual rainfall; some of the worst destruction is wrought in regions where a low total is concentrated into short intense spells.
As soon as the rate of fall becomes sufficient to cause an actual flow of water at any spot it acquires an excavating power and begins to cut a channel in the loose earth, a gulley which not only enlarges itself by the undercutting of its banks but also tends to eat its way backwards. Gulleying can be initiated either by careless management of cultivated soil or on grassland by overgrazing, which bares the surface. Even before actual overgrazing sets in, both cattle and sheep will tread bare tracks along which streams will begin to flow during the rains and to acquire sufficient velocity to eat into the soil. In however small a way such gulleying starts, if it is not checked it extends itself from season to season, until eventually, by a sort of geometrical progression, the large area may become impassable to man and beast. Though agriculture generally is indicted as the initiator of erosion, more properly it is the recklessness or the want of foresight in man that should be blamed. Erosion is like fire; a trivial accident may start it, and if not checked at once there may be no staying its progress.

In a recent book "Rich Land, Poor Land" is described a great crater in Georgia, 200 feet deep, that had arisen from a simple gully. "Do you know what started him? A trickle of water running off a farmer's barn 40 years ago. Just one dam little trickle, and now a third of the county's gone-forty thousand acres." An area in Tennessee ten miles in diameter has been gullied to desolation through destruction of the vegetation by the fumes of a copper smelter.

The loss of land is not all that the community suffers. The soil that the rain starts moving reaches the rivers and has to find a resting-place somewhere. It is in regions liable to erosion that irrigation becomes of so much importance, and dams are thrown across the rivers to store the flood-water of the rains. But no one had foreseen what masses of sand and silt would begin to choke the reservoirs when erosion was going on at the head waters. The Rio Perco is reported to be pouring every flood season 9,000 acre feet of silt into the lake built to supply New Mexico with its quota of water from the Rio Grande. The last Mississippi flood was the wildest and most dangerous of any in the history of the river, notwith. standing all the protective measures that have been carried out, simply because the lower river is being raised more and more above the level of the surrounding country.

A large amount of work is now being done in the United States to control gulleying and to reclaim the devastated land. In the early stages, gulleying can be checked by throwing dams across the gash, dams which may be timber or concrete or just bushes, alive or dead, anything that will 
check the rush of water and cause the sediment to begin to accumulate. Even more effective has been the introduction of rapidly growing plants, which not only check the flow of water and filter out the silt but also bind the earth and stop further washing. The Soil Conservation Service in the United States is bringing into play all the resources of science and engineering to repair the damage which had been inflicted upon the land of the United States by hasty exploitation. I would instance again the Civilian Conservation Corps, that inspiration of President Roosevelt's, which in 1932, when the youth of America found no prospect of employment of any kind on leaving school or college, gathered some 300,000 of them for service and set them to work to clean up the countryside. They were turned on to fireprevention work in the forests, to checking erosion, to road making and vermin destruction in the national parks, to various forms of reclamation and salvage work-the corps itself being the most magnificent piece of human salvage this generation has known. One cannot but think that it would be of value to the population of Britain if all our young men could be conscripted for six months of their life to carry out public work for the improvement of our countryside.

The examples of erosion so far considered are due to the unthinking exploitations of the soil by civilized men. Similar destruction of the land is, however, taking place in Africa, where the tribes have not arrived at a system of farming that conserves the fertility of the oil, but practise the more primitive form of 'shifting cultivation'. The cultivator is allotted a particular plot in the area of jungle or bush belonging to his clan; this he, or rather his wives, clears, perhaps burning off the timber before putting in his crop. In two or three years the soil begins to become exhausted or weeds become intractable, whereupon the plot is abandoned and a new piece is taken up. The abandoned plot is soon covered with the natural vegetation, and in the course of time, perhaps ten, perhaps thirty years, recovers sufficiently to be ready to take into cultivation again. Thus the tribe requires many times as large an acreage of land as is actually in cultivation at any one time, and if the tribe is increasing in numbers it will be eating pretty steadily into hitherto unoccupied grassland or forest.

One other feature is of importance. The Bantu tribes, who predominate in East Africa, attach the greatest value to livestock, particularly to cattle. Cattle represent wealth and position; they are intimately bound up in tribal custom with the marriage ceremonies-indeed they enjoy a definitely religious status. They are the essential consideration that has to be tendered for a wife. But they serve little or no economic purpose. They are not eaten except ceremonially, by many tribes they are not milked, they are not beasts of burden, neither is their dung used as manure. Sheep and goats are in the same category; they are less sacred and less valuable; their only economic product is their skins for clothing.

Consider the consequences: within this century British rule has maintained peace among the tribes, and with the cessation of raiding, numbers have been rising steadily. According to census returns, the native population in the Union of South Africa has doubled in the last fifty years ; in Basutoland the estimated population multiplied fourfold between 1879 and 1921. In Kenya the annual rate of increase is estimated at about $1 \frac{1}{2}$ per cent, which means doubling the numbers in forty-six years, and similar estimates are made for the Nandi tribes in the Kavirondo and for the Uganda population.

The increase of human population has been accompanied by an even greater increase in the numbers of livestock, which in the old days had been effectively kept under by raiding. With these checks gone, the animal population has outgrown the means of sustenance, and even in some districts is destroying the vegetation in uncultivated areas which should be regenerating against their turn to be brought into cultivation. The Native Economic Commission of South Africa, reporting in 1932, stated: "With the exception of certain parts of Zululand and Pondoland every native area is overstocked", and estimates that between 1918 and 1930 cattle increased from 7 to 17 hundred thousand, and sheep from 21 to nearly 4 million. The Kenya Land Commission, reporting in 1933, wrote: "Probably about 1920 the main stock areas of the native reserves had attained their optimum carrying capacity, and although fully stocked, were not overstocked. Since then the cattle population has-roughly speakingdoubled itself". Again, of the Kamba reserve : "Mr. Scott Little estimates that the reserve contains 190,000 cattle with 57,000 calves, though he estimates its grazing capacity at no more than 60,000 head. There are also 260,000 goats and 150,000 sheep. A journey through the area east and south of Machakos reveals that over large stretches of hillsides vegetation has been almost wholly removed. The soil has been eroded down to the subsoil and its removal will continue at an ever-increasing rate. On less steep slopes and on better land vegetation still persists, and though the Wakamba are primarily a pastoral tribe, patches of cultivation are in evidence. But even there grazing has been so persistent that the ground is all beaten down into little stock paths and has become in turn open to erosion". 
Mr. C. W. Hobley, giving evidence about Tanganyika, said: "The native occupier, if space permits, moves on, leaving exhausted soil and desert behind him". Prof. E. P. Stebbing has uttered strong warnings of the encroachment of the Sahara upon northern Nigeria, due to shifting cultivation and overstocking in the forest. Major Grogan put the matter brutally when he said before the Kenya Land Commission: "The African people have never established a symbiotic relationship with land. They are, in the strict scientific sense, parasites on the land, all of them", and in another place he speaks of flying over Central Africa and picking out the eroded areas by their colour.

These instances will suffice; over a large part of Africa-the eastern side from the Abyssinian frontier down to the Cape, Uganda and parts of Nigeria, everywhere indeed except in the tropical rain-forest of the western seaboard and interiorconditions are such as render erosion by washing a danger. Further, there is a native population practising a destructive form of agriculture and keeping a vast uneconomic head of stock, including the devastating goat in large numbers; they are eating rapidly into such forest areas as are left open. Small wonder that famine is never far away from some of the tribes, that the major political issue between native and white man is the cry for more land. Yet even if there were more land to give, the day of reckoning would only be deferred, the new land would only be eaten up in its turn; the native must either change his methods or limit his numbers. Indeed, the situation has even now gone so far that from time to time the Government has to import food to save a tribe from starvation.

It is but recently that the dangers of erosion in Africa have come to be realized. However, it is now evident that all the African colonies have become erosion conscious, as may be seen from Sir Frank Stockdale's report on his recent tour through Africa.

Much yet remains to be done before the arrears of years of misuse of the soil can be repaired and before the native population can be educated to systems of farming which will maintain the fertility of the land. Not only have drastic changes in native custom to be brought about, but also in many cases expenditure is called for which can scarcely be found within the limited resources of the particular colony.

The regeneration of wasted areas must begin with closing them for a time to grazing, so as to allow the return of natural vegetation; if the land has not been very badly denuded, recovery is rapid; but in places it may be necessary to introduce specially useful plants like the stoloniferous grasses so characteristic of South Africa. A certain amount of minor engineering is needed to check run-offs and dongas by dams or plantations. Measures to deal with the invading weeds like Striga in Central Africa or the Chrysocoma of the south are still lacking. At the same time cultivators, both natives and white settlers, are being taught the virtues of contour ploughing and planting, and of vegetation strips in cultivated land to break up run-off.

Such measures, however, do not touch the major cause of erosion-overstocking. Legislative action is necessary to compel a reduction in the head of stock. The drastic culling that is called for must be done by way of purchase, and since the animals which would first be drafted are practically valueless for food, one or more meat factories would be required to turn the carcasses into manure and then into successively better products as the quality of the culls improved. A reduction in the numbers of cattle or sheep to one half or so would not only relieve the pressure on the land but also would give the native owners some chance of improving quality both by selection and by better feeding, whereas at present numbers alone are valued. Education should also proceed to induce the natives to use cattle economically for milk or meat and for traction, or at least to sell them for food.

Even more fundamental must be the education of the natives to adopt a conservative system of farming - a rotation that would include leguminous crops and so help the native dietary as well as restore nitrogen to the soil. Compost-making is another method of maintaining fertility which is being taught to the natives. The African cannot increase, cannot even maintain, his present numbers unless he learns how to use his plot of land so that it will continuously produce food.

But it is difficult to speak temperately of the urgent need for effort in this direction on a large scale. Many of the tribes are on the verge of starvation, the desert is growing apace, and as the cropping or grazing area shrinks, the pressure upon it becomes greater, and destruction proceeds at a compound interest rate.

The responsibility for action lies not only on the Colonial Governments but also on the British Government itself. It has declared itself trustec for the native populations; it must save them from themselves. Other nations are demanding colonies in Africa as sources of raw materials and as openings for colonization, but as soon as one gets away from the few mineral areas African land affords little opportunity of exploitation, and will indeed only continue to exist productively if its overlords adopt and persist in a self-denying policy. 